ks. Jan Dyduch

Uniwersytet Papieski Jana PaWea II

\title{
Małżeństwo
}

\section{sakramentalnym przymierzem}

Naucza Sobór Watykański II: „Głęboka wspólnota życia i miłości małżeńskiej, ustanowiona i wyposażona w prawa przez Stwórcę, powstaje na mocy przymierza małżeńskiego, czyli nieodwołalnej zgody osobowej”. Odnowiona wizja małżeństwa, zaprezentowana w powyższej formule soborowej, nazywa je przymierzem. Przymierze to, ustanowione przez Boga, jest zawsze przymierzem religijnym. Zostało ono przez Jezusa Chrystusa podniesione do godności sakramentu. Małżeństwo jest przymierzem zarówno in statu fieri, jak i in statu esse. Przymierze in statu esse stanowi równocześnie głęboką wspólnotę życia. Przywołane problemy zamierzamy omówić w niniejszym artykule.

\section{Małżeństwo religijnym przymierzem}

Małżeńskie przymierze sięga swymi początkami dzieła stworzenia. To Bóg jako ukoronowanie swojego stwórczego dzieła stwarza człowieka. Naucza Pismo Święte: „Stworzył więc Bóg człowieka, na swój obraz, na obraz Boży go stworzył: stworzył mężczyznę i niewiastę" ( $R d z 1,27)$. Stworzył człowieka jako dwie różniące się osoby. Bóg im pobłogosławił, polecając: „Bądźcie płodni i rozmnażajcie się, abyście zaludnili ziemię i uczynili ją sobie poddaną...."

1 Sobór Watykański II, konst. Gaudium et spes [dalej: KDK], 48. 
(Rdz 1, 28). Tak więc przymierze małżeńskie ustanowione przez Boga Stwórcę jest związkiem religijnym. Bóg wyposażył małżeństwo w swoje prawa, ustanawiając je jako instytucję trwałą. Tak ukształtowany węzeł jest święty².

Przymierzu małżeńskiemu, które ma naturę religijną, nadał Bóg swoje prawa i zasady, np. nierozerwalność. Tych konstytutywnych zasad człowiek nie może zmieniać ani ignorować, ponieważ nie leży to w jego kompetencji. Może je jedynie uzupełniać, lecz tylko tak, aby to, co w przymierzu małżeńskim pochodzi od Boga, a więc prawo Boże, zostało zachowane i nienaruszone. Określenia „przymierze małżeńskie” nie znajdujemy w Piśmie Świętym. Jednak rzeczywistości, jaką stanowi małżeństwo tam zaprezentowane, bardzo odpowiada to określenie. Nauczanie Vaticanum II nazwało małżeństwo „przymierzem”, ubogacając dotychczas funkcjonujący w prawie termin „kontrakt” czy „umowa”. Wydaje się, iż termin „przymierze” odzwierciedla religijną i świętą rzeczywistość małżeństwa pełniej niż termin „kontrakt”. Kontrakty dotyczą bardziej rzeczy, przedmiotów, przymierze zaś osób. Kontrakty zazwyczaj zawiera się na czas określony, przymierze na zawsze. Kontrakty mogą czasem ulec zerwaniu czy wygaśnięciu z powodu zniszczenia lub utraty rzeczy będących ich przedmiotem. Przymierza nie da się zerwać. Poręczycielem kontraktu jest lud, państwo, zaś gwarantem przymierza jest Bóg3.

Charakterystyczną cechą przymierza małżeńskiego jest miłość. Naucza Jan Paweł II: „Komunia miłości pomiędzy Bogiem i ludźmi, stanowiąca zasadniczą treść objawienia i doświadczenia wiary Izraela, znajduje swój wymowny wyraz w przymierzu oblubieńczym zawartym pomiędzy mężczyzną i kobietą” 4 Przymierze

\footnotetext{
2 Por. KDK 48.

3 Por. P. Palmer, Konieczność teologii matżeństwa, „Communio, Międzynarodowy Przegląd Teologiczny" 1 (1981) nr 5, s. 23.

4 Adhort. apost. Familiaris consortio, 22 XI 1981 [dalej: FC], 12.
} 
małżeńskie opromienione miłością jest odzwierciedleniem głównego przekazu objawienia, iż Bóg miłuje swój lud. Jest to miłość wierna, będąca wzorem dla miłości małżeńskiej, która winna łączyć małżonków5 ${ }^{5}$ Nowe i pogłębione spojrzenie na miłość małżeńską jawi się w nauczaniu Soboru Watykańskiego ${ }^{1}{ }^{6}$. Vaticanum II naucza: „Także w naszych czasach wielu ludzi wysoko ceni prawdziwą miłość pomiędzy mężem i żoną, przejawiającą się na różne sposoby, stosownie do szlachetnych obyczajów narodów i czasu"7. Do tej sprawy wrócimy poniżej.

Przymierzu małżeńskiemu ustanowionemu przez Boga w raju została nadana przez Stwórcę świetlana przyszłość. W ten plan Boży uderzył człowiek, który - pod wpływem pokusy szatana popełnił grzech zwany pierworodnym. To tragiczne wydarzenie w dziejach ludzkości spowodowało opłakane skutki, między innymi obraz Boży w człowieku został przyćmiony, ale nie wymazany, natura ludzka została zraniona, dotknięte boleśnie zostało przymierze małżeńskie, zakończyła się pierwotna przyjaźń człowieka ze swoim Stwórcą. Stan upadłej ludzkości, dotkniętej nie tylko grzechem pierworodnym, ale także własnymi grzechami osobistymi i społecznymi, pogrążył również małżeństwo, a zwłaszcza ono.

Ten stan upadłej ludzkości określa Jezus „zatwardziałością serc ludzkich” (por. Mt 19, 8). Warto przywołać ewangeliczny kontekst tego określenia. Jezus prowadzi dialog z faryzeuszami, stawiającymi pytanie: „Czy wolno oddalić swoją żonę z jakiegokolwiek powodu?". Jezus odpowiada, że nie wolno, przywołując dzieło stworzenia: „Czy nie czytaliście, że Stwórca od początku stworzył ich jako mężczyznę i kobietę?” (Mt 19, 4). Wówczas faryzeusze, odwołując się do Mojżesza, który dla Żydów był niesłychanym

5 Por. FC 12.

6 Por. KDK 49-50.

7 KDK 49. 
autorytetem, pytają: „Czemu więc Mojżesz polecił dać jej list rozwodowy i odprawić ją?" (Mt 19, 7). Odpowiadając, Jezus ponownie odwołuje się do rzeczywistości stworzenia: „Przez wzgląd na zatwardziałość serc waszych pozwolił wam Mojżesz oddalać wasze żony; lecz od początku tak nie było" (Mt 19, 8).

W przytoczonej rozmowie Jezus wygłasza swoją naukę, podkreślając: „Dlatego opuści człowiek ojca i matkę i złączy się ze swoją żoną, i będą oboje jednym ciałem" (Mt 19, 5). W tym stwierdzeniu nie chodzi o fizyczną jedność mężczyzny i kobiety, lecz o jedność i nierozerwalność przymierza małżeńskiego. To Jezus potwierdza swoją konkluzją: „Co więc Bóg złączył, niech człowiek nie rozdziela” (Mt 19, 6). Tak więc małżeństwo ustanowione przez Boga w dziele stworzenia jest przymierzem religijnym i nierozerwalnym. Każde małżeństwo jako rzeczywistość naturalna jest zakorzenione w ekonomii stworzenia i pochodzi od Boga, stąd ma charakter religijny ${ }^{8}$. Dlatego, zgodnie z nauczaniem Kościoła, małżeństwa zawarte przez niechrześcijan poza Kościołem katolickim, w oparciu o prawo naturalne, są ważne i nierozerwalne9 ${ }^{9}$

Nawiązując do powyższych wywodów, trzeba stwierdzić, iż Jezus Chrystus przywrócił małżeństwu jego pierwotną godność nierozerwalnego przymierza religijnego, a następnie przez dzieło odkupienia nadał mu nową godność przymierza sakramentalnego. Dlatego słusznie naucza II I Nadzwyczajny Synod Biskupów: „Z przyjściem Jezusa i pojednaniem upadłego świata, dzięki dokonanemu przez Niego odkupieniu, zakończyła się epoka rozpoczęta przez Mojżesza”». Zakończyła się epoka legalności i dopuszczalności rozwodów, a rozpoczęła się epoka małżeństwa

8 Por. M. Żurowski, Eklezjalny charakter małżeństwa i rodziny, „Prawo Kanoniczne" 21(1978) nr 3-4, s. 108-109.

9 Por. M. Żurowski, Kanoniczne prawo matżeńskie Kościoła Katolickiego, Katowice 1987 , s. 400-401.

10 Relatio Synodi, $18 \times 2014,15$. 
jako nierozerwalnego przymierza sakramentalnego. Do tej prawdy nawiązuje papież Franciszek: „W kwestii małżeństwa Kościół, przez wieki będąc coraz bardziej świadomy słów Chrystusa, rozumiał i przedstawiał w sposób dogłębny doktrynę o nierozerwalności świętego węzła małżeńskiego" ${ }^{11}$.

\section{Sakramentalność małżeństwa}

Sobór Watykański II naucza: „Jak bowiem niegdyś Bóg wyszedł na spotkanie swojemu ludowi poprzez przymierze miłości i wierności, tak teraz Zbawiciel ludzi i Oblubieniec Kościoła przez sakrament małżeństwa wychodzi na spotkanie chrześcijańskim małżonkom"12. Nauczanie i działalność Jezusa Chrystusa sprawiają, że porządek stworzenia dotyczący małżeństwa został ubogacony w dwojaki sposób. Najpierw został uporządkowany i odnowiony sam porządek naturalny przez to, że Jezus przywrócił pierwotną godność małżeństwu jako nierozerwalnemu przymierzu o charakterze religijnym, które normowane jest prawem Bożym naturalnym, a następnie uzupełnionym prawem pozytywnym, zarówno Bożym, jak i kościelnym, lecz zgodnym z prawem Bożym. Tak należy postrzegać obecność Jezusa i Jego Matki na godach w Kanie Galilejskiej, gdzie na prośbę swej Matki Jezus dokonał pierwszego cudu (por. J 2, 1-11). Następnie Jezus nadaje małżeństwu nową nadprzyrodzoną godność, ustanawiając je sakramentem. Naucza III Nadzwyczajny Synod Biskupów: „Ze względu na Bożą pedagogię, zgodnie z którą porządek stworzenia przechodzi w porządek odkupienia poprzez kolejne etapy, należy rozumieć nowość sakramentu małżeństwa w ciągłości z pierwotnym małżeństwem naturalnym”’3. Tak więc rzeczywistość stworzenia - naturalne

\footnotetext{
11 Motu proprio Mitis Iudex Dominus Iesus, 15 VIII 2015 [dalej: MIDI].

12 KDK 48.

13 Relatio Synodi, 13.
} 
przymierze małżeńskie - ustanowił Jezus sakramentalnym przymierzem, ubogacając je rzeczywistością nadprzyrodzoną oraz jednocząc w sobie te dwie rzeczywistości tak, że powstaje jedno małżeństwo, będące jednym przymierzem sakramentalnym. Podobnie jak Kościół, wspólnota Ludu Bożego, w której pierwiastek boski, nadprzyrodzony, niewidzialny - Mistyczne Ciało Chrystusa - zrasta się z pierwiastkiem ludzkim, przyrodzonym, widzialnym, w jedną rzeczywistość Bosko-ludzką ${ }^{14}$ Naucza Vaticanum II: „Ponieważ Kościół jest w Chrystusie jakby sakramentem, czyli znakiem i narzędziem wewnętrznego zjednoczenia z Bogiem i jedności całego rodzaju ludzkiego [...]" ${ }^{15}$. W przywołanym nauczaniu soborowym nie chodzi o nowy, ósmy sakrament, lecz o to, że Kościół ma strukturę sakramentalną. To znaczy, że zewnętrzny znak jest narzędziem łaski Bożej.

Taka też jest struktura sakramentalnego przymierza małżeńskiego. Widzialne przymierze małżeńskie jest narzędziem niewidzialnej łaski Bożej. Nauczanie o sakramentalności małżeństwa ma swoje uzasadnienie w Nowym Testamencie, w szczególności w Liście św. Pawła Apostoła do Efezjan (5, 22-33). Pisze św. Paweł: „Żony niechaj będą poddane swym mężom, jak Panu, bo mąż jest głową żony, jak i Chrystus - Głową Kościoła: On - Zbawca Ciała. Lecz jak Kościół poddany jest Chrystusowi, tak i żony mężom we wszystkim. Mężowie miłujcie żony, bo i Chrystus umiłował Kościół [...]” (Ef 5, 22-25). W nauczaniu św. Pawła są wymienione wszystkie elementy sakramentalne. Małżeństwo jest znakiem widzialnym, zewnętrznym nierozdzielnej wspólnoty Chrystusa z Kościołem. Wzajemne przymierze dwóch osób powstaje przez uzewnętrznione wyrażenie zgodnej woli i tworzy wspólnotę na podobieństwo Chrystusa z Kościołem. To zewnętrzne przymierze

14 Por. nauczanie o Ludzie Bożym кK, 9-17.

15 KK 1. 
jest znakiem łaski i jej udzieleniem w Kościele przez Chrystusa. Znak ten udziela łask, gdyż obowiązki nałożone na małżonków, zarówno obowiązki żony wobec męża, jak i męża względem żony, należą do porządku nadprzyrodzonego. Relacje w sakramentalnym przymierzu małżeńskim oparte są na miłości, która winna być poniekąd odzwierciedleniem miłości Chrystusa do Kościo$\mathrm{ła}^{16}$. Sakramentalne przymierze małżeńskie mogą zawrzeć tylko ochrzczeni. Należy ono jednocześnie do porządku stworzenia i do porządku odkupienia. Małżeńskie przymierze zapoczątkowane w dziele stwórczym Boga uzyskuje nową godność i ubogacenie w dziele odkupienia Jezusa Chrystusa: „Przymierze małżeńskie zapoczątkowane w dziele stworzenia i objawione w historii zbawienia zyskuje pełne objawienie swego znaczenia w Chrystusie i w Jego Kościele. Od Chrystusa za pośrednictwem Kościoła małżeństwo i rodzina otrzymuje potrzebną łaskę, by dać świadectwo miłości Boga i żyć życiem komunii” ${ }^{17}$. Nauczanie soborowe podkreśla godność przymierza małżeńskiego, charakteryzującego się zdolnością uświęcania małżonków i zdobywania świętości dzięki łasce sakramentalnej: „Wreszcie małżonkowie chrześcijańscy na mocy sakramentu małżeństwa, przez który wyrażają misterium jedności i płodnej miłości pomiędzy Chrystusem i Kościołem oraz w nim uczestniczą (por. Ef 5, 32), wspierają się wzajemnie w życiu małżeńskim, w przyjęciu i wychowaniu potomstwa, celem zdobycia świętości [...]”18.

Religijne przymierze małżeńskie podniesione do godności sakramentu zostaje ubogacone świętością, darem Jezusowej łaski dla małżonków i dzieci. Dar sakramentu sprawia, że małżeńskie przymierze staje się jeszcze większą jednością, a jego nierozerwalność

\footnotetext{
16 Por. M. Żurowski, Kanoniczne prawo matżeńskie..., dz. cyt., s. 31-32.

17 Relatio Synodi, 16.

18 KK 11.
} 
zostaje umocniona i potwierdzona. Nauczanie o sakramentalności przymierza małżeńskiego reasumuje Kodeks prawa kanonicznego [dalej: KPK] w sposób następujący: „§ 1. Małżeńskie przymierze, przez które mężczyzna i kobieta tworzą ze sobą wspólnotę całego życia, skierowane ze swej natury do dobra małżonków oraz zrodzenia i wychowania potomstwa, zostało pomiędzy ochrzczonymi podniesione przez Chrystusa Pana do godności sakramentu. § 2. Z tej racji między ochrzczonymi nie może istnieć ważna umowa małżeńska, która tym samym nie byłaby sakramentem" (kan. 1055).

Nie jest sakramentem małżeństwo ważnie zawarte przez osoby nieochrzczone, gdyż nie są one zdolne do przyjęcia żadnego sakramentu oprócz chrztu. Od czasu jednak przyjęcia przez takich małżonków sakramentu chrztu ich małżeństwo bez żadnych dodatkowych aktów staje się sakramentem. W przypadku zawarcia małżeństwa osoby ochrzczonej z nieochrzczoną według formy kanonicznej, na podstawie dyspensy od przeszkody różnej wiary, małżeństwo takie jest ważne, lecz - zgodnie ze zdaniem większości autorów - nie jest sakramentem ${ }^{19}$. Można by tutaj przywołać opinię niektórych dawniejszych autorów, opowiadających się za tym, że tylko dla strony ochrzczonej takie małżeństwo jest sakramentem $^{20}$. Nauczanie soborowe o przymierzu małżeńskim jako głębokiej wspólnocie życia i miłości przemawia przeciw powyższej opinii. W przypadku przyjęcia chrztu przez małżonka nieochrzczonego, małżeństwo takie staje się sakramentem.

W kontekście zawierania sakramentalnego przymierza małżeńskiego trzeba zapytać o wiarę kandydatów do małżeństwa. Czy jest ona potrzebna do ważnego zawarcia małżeństwa? Jan

19 Por. T. Pawluk, Prawo kanoniczne wedtug Kodeksu Jana Pawła II, t. 3, Olsztyn 1984 , s. 26.

20 Por. F. Bączkowicz, Prawo kanoniczne, Opole 1958, t. 3, wyd. 3, s. 154-155. 
Paweł II daje na to pytanie następującą odpowiedź: „Nie powinno się jednak zapominać, że ci narzeczeni na mocy chrztu są już rzeczywiście włączeni w oblubieńcze przymierze Chrystusa z Kościołem i że przez dobrą intencję przyjęli zamysł Boży odnoszący się do małżeństwa, a zatem, przynajmniej implicite, chcą tego, czego chce Kościół, kiedy sprawuje obrzęd sakramentalny małżeństwa”21. Ustalanie stopnia wiary nowożeńców przy dopuszczaniu ich do zawarcia małżeństwa papież uważa za błędne. Niemniej jednak stwierdza, że nowożeńców odrzucających wyraźnie i formalnie to, co Kościół chce dopełnić sprawując obrzęd małżeństwa ochrzczonych, nie należy dopuścić do tego obrzędu ${ }^{22}$. Sprawa ta wymaga odrębnego, szerszego omówienia, tym bardziej że motu proprio papieża Franciszka Mitis Iudex Dominus Iesus z 15 sierpnia 2015, reformujące kanoniczny proces małżeński, w dołączonych normach proceduralnych stwierdza, że brak wiary, mogący prowadzić do symulacji konsensu małżeńskiego lub błędu determinującego wolę, stanowi okoliczność upoważniającą do przeprowadzenia skróconego procesu małżeńskiego o stwierdzenie nieważności małżeństwa ${ }^{23}$.

\section{Cele i zadania wspólnoty małżeńskiej}

Sakramentalne przymierze małżeńskie ma swoje cele i zadania. Zostały one w nowym świetle ukazane przez nauczanie Soboru Watykańskiego II. Vaticanum II naucza: „To sam Bóg jest Stwórcą małżeństwa wyposażonego w różne dobra i cele; wszystkie one mają ogromne znaczenie dla przedłużenia rodzaju ludzkiego, rozwoju osobowego i życia wiecznego poszczególnych członków rodziny oraz dla godności, trwałości, pokoju i pomyślności samej

\footnotetext{
21 FC 68.

22 FC 68.

23 MIDI, Zasady proceduralne, art. 14, § 1.
} 
rodziny i całego rodzaju ludzkiego" ${ }^{24}$. Tak więc celem małżeństwa jest dobro samych małżonków, dobro ich rodziny i dobro ludzkości.

Inne ujęcie celów małżeństwa prezentował KPK z 1917 roku. Za pierwszorzędny cel małżeństwa uważał zrodzenie i wychowanie potomstwa, zaś za drugorzędny - wzajemną pomoc i zaspokojenie popędu (por. kan. 1013 § 1). Nauczanie soborowe odchodzi od tego zagęszczonego sposobu prezentowania celów małżeństwa, a ujmuje je i naświetla bardziej personalistycznie, akcentując miłość małżeńską. Chodzi o miłość wybitnie ludzką, skierowaną od osoby do osoby. Taka miłość i towarzyszące jej uczucie obejmują dobro całej osoby. Naucza Vaticanum II: „Miłość tę nasz Pan uzdrowił, udoskonalił i wyniósł szczególnym darem swej łaski i miłości. Miłość taka, łącząca w sobie wartości ludzkie i Boże, prowadzi małżonków ku wolnemu i wzajemnemu darowi z samych siebie [...]"25. Dlatego prawdziwa miłość małżeńska włączona jest w miłość Bożą, która jest kierowana i obdarowywana mocą Chrystusa oraz zbawczym działaniem Kościoła, dzięki czemu małżonkowie są prowadzeni do świętości i wspomagani w spełnieniu zaszczytnego zadania ojca i matki ${ }^{26}$.

Spełnianie tego zadania, wypływającego z przymierza małżeńskiego, jest bardzo mocno akcentowane w nauczaniu soborowym: „Instytucja małżeństwa i miłość małżeńska z natury są ukierunkowane na prokreację i wychowanie potomstwa, a to stanowi jakby ukoronowanie powołania małżonków"27. Dzieci stanowią najwspanialszy dar małżeństwa i bardzo przyczyniają się do dobra samych rodziców. Prawdziwa miłość małżeńska, opromieniająca całe życie małżeńskie i rodzinne, zmierza do tego, aby małżonkowie, nie zaniedbując pozostałych celów małżeństwa, byli gotowi

\footnotetext{
24 KDK 48.

25 KDK 43.

26 Por. KDK 48.

27 KDK 48.
} 
do mężnego współdziałania z miłością Stwórcy i Zbawcy, który poprzez nich coraz bardziej powiększa i ubogaca swoją rodzinę ${ }^{28}$.

Współpraca małżonków z miłością stwórczą Boga jest ich szlachetnym zadaniem: „Małżonkowie wiedzą, iż są współpracownikami miłości Boga Stwórcy i jak gdyby interpretatorami w zakresie obowiązku przekazywania życia i wychowania, które winny być uważane za ich właściwe zadanie" ${ }^{29}$. To zadanie winni wypetniać w duchu ludzkiej i chrześcijańskiej odpowiedzialności oraz szacunku dla Boga i jego przykazań. Sakramentalne przymierze małżeńskie jest fundamentem rodziny chrześcijańskiej, dlatego małżonkowie mają dążyć do dobra własnego, jak i do dobra dzieci czy to już urodzonych, czy też oczekiwanych w przyszłości, uwzględniając warunki czasowe, jak i okoliczności życiowe. Troszcząc się o własną rodzinę, małżonkowie winni mieć na uwadze dobro wspólnoty doczesnej i wspólnoty kościelnej. W swoim sposobie postępowania odnośnie do rozwoju rodziny winni kierować się sumieniem zgodnym z prawem Boskim, posłuszni Nauczycielskiemu Urzędowi Kościoła. Na szczególne uznanie zasługują ci małżonkowie, którzy wierni swojemu powołaniu, wielkodusznie podejmują się odpowiedzialnego wychowania nawet liczniejszego potomstwa $^{30}$.

Istotny cel małżeństwa, zrodzenie i wychowanie potomstwa, pozostawia miejsce na inne jego cele: „Małżeństwo nie zostało ustanowione jedynie w celu zrodzenia dzieci [...]. Dlatego, choćby brakowało tak często upragnionego potomstwa, małżeństwo trwa jako związek i wspólnota całego życia, zachowując znaczenie i nierozerwalność" ${ }^{31}$. Nauczanie soborowe ujmuje całościowo cele małżeństwa. Nie tylko te pierwszorzędne, ale i drugorzędne,

28 Por. KDK 5 O.

29 KDK 50.

30 Por. KDK 50.

31 KDK 50. 
które przedstawia, jako harmonijną całość. Akcentuje też wielką rolę i znaczenie w pełni ludzkiej miłości małżeńskiej, nie tylko psychologiczno-uczuciowej, lecz także duchowo-nadprzyrodzonej. Taka miłość sprawia, że współmałżonek oddaje się drugiemu i współdziała w budowaniu tej podstawowej komórki społecznej i kościelnej, jaką jest rodzina. Tak więc cel małżeństwa stanowi pewną jedność w wielości, a jego poszczególne elementy tworzą jedną, zwartą i ściśle powiązaną całość32.

Sobór Watykański II, nazywając małżeństwo „głęboką wspólnotą życia i miłości”, dowartościował prawdziwą miłość małżeńską33. Mimo to ważna pozostaje tradycyjna zasada, że małżeństwo powstaje poprzez wyrażenie zgody zawierających je stron, natomiast miłość małżeńska posiada walor psychologiczny, a nie prawny. To wcale nie pomniejsza znaczenia miłości, nie znaczy, iż jest ona drugorzędna i niepotrzebna ${ }^{34}$.

Naucza Jan Paweł II: „Miłość pomiędzy kobietą i mężczyzną w małżeństwie i w formie pochodnej i rozszerzonej, miłość pomiędzy członkami tej samej rodziny - pomiędzy rodzicami i dziećmi, pomiędzy braćmi i siostrami, pomiędzy krewnymi i domownikami - jest ożywiana i podtrzymywana przez zewnętrzny, nieustający dynamizm, prowadzący rodzinę do coraz głębszej i mocniejszej komunii, która jest fundamentem i zasadą wspólnoty małżeńskiej i rodzinnej”35.

Z celami małżeństwa łączy się tradycyjne nauczanie o dobrach małżeństwa, gdyż sam Bóg tak ukształtował przymierze małżeńskie, że ma ono różnorodne dobra i cele ${ }^{36}$. O tych celach była mowa wyżej. Tradycyjnie wymienia się, za św. Augustynem, trzy dobra

32 Por. M. Żurowski, Kanoniczne prawo matżeńskie..., dz. cyt., s. 44-45.

33 Por. KDK 48.

34 Por. T. Pawluk, Prawo kanoniczne..., dz. cyt., s. 54.

35 FC 18.

36 Por. KDK 48. 
małżeństwa: dobro potomstwa (bonum prolis), dobro wierności (bonum fidei) i dobro sakramentu (bonum sacramenti) ${ }^{37}$. Naucza Vaticanum II, że nierozerwalna małżeńska wspólnota życia i miłości służy zarówno dobru małżonków jak i dzieci: „[...] węzeł ten, święty ze względu na dobro zarówno małżonków i potomstwa, jak i społeczeństwa, nie zależy od sądu ludzkiego" ${ }^{38}$. Tak więc przymierze małżeńskie, charakteryzując się dobrem sakramentu, z natury swej zmierza do dobra małżonków. Te tradycyjnie wymieniane trzy dobra uczestniczą w dobru małżonków, a dobro małżonków poniekąd się w nich mieści. Wydaje się, że tak rzeczywistość harmonii tradycyjnych dóbr przymierza małżeńskiego z dobrem małżonków postrzega крк (por. kan. 1055 § 1).

\section{Zakończenie}

W odnowionej i pogłębionej nauce Vaticanum II o małżeństwie jawi się ono jako sakramentalne przymierze. Małżeństwo ustanowione przez Boga Stwórcę u samych początków ludzkości jako nierozerwalny związek mężczyzny i kobiety zostało podniesione do godności sakramentu przez Jezusa Chrystusa. Małżeństwo, realizujące swoje cele i zadania, staje się podstawą rodziny, której największym darem są dzieci. Małżeństwo i rodzina potrzebują ustawicznej troski Kościoła, która wyraża się w intensywnym duszpasterstwie regulowanym odpowiednimi wskazaniami i normami. Wyrazem tej troski jest nauczanie Synodu Biskupów, obradującego w dniach 4-25 października 2015 roku, na temat roli i zadań małżeństwa i rodziny.

37 Por. T. Pawluk, Prawo kanoniczne..., dz. cyt., s. 54-55.

38 KDK 48. 


\section{SUMMARY}

\section{Marriage as a sacramental covenant}

God: created marriage between a man and a woman as indissoluble matrimonial unity. The natural marriage has been raised by Christ the Lord to the dignity of a sacrament, but only between the baptized persons. In this way the matrimonial covenant connects harmonically natural dignity with supernatural dignity. The connection in question creates a foundation for a Christian family. A family is the first and vital cell of any society („prima et vitalis cellula societatis”). It is the main reason why family should be the object of care and protection by Church and a state.

Keywords: religious covenant, sacramental covenant, aims and good of marriage, Christian family

Jan Dyduch, Małżeństwo sakramentalnym przymierzem, [w:] Znaczenie wiary dla małżeństwa: w kierunku zmiany prawa, red. Piotr Kroczek, Kraków 2016, s. 7-20 (Annales Canonici Monographiae, 4).

DOI: http://dx.doi.org/10.15633/9788374385220.02 